\title{
Cytokine Receptor Binding
}

National Cancer Institute

\section{Source}

National Cancer Institute. Cytokine Receptor Binding. NCI Thesaurus. Code C40487.

A process that involves the binding of any member of the cytokine family to a cognate cytokine receptor. These interactions are involved in the regulation of responses that promote antibody synthesis and cellular immune functions. 